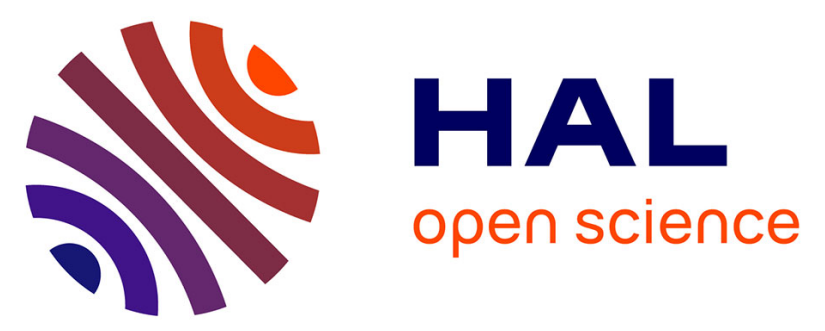

\title{
Does Epoetin Beta Still Have a Place in Peginterferon Alpha-2a Plus Ribavirin Treatment Strategies for Chronic Hepatitis C?
}

Pascal Veillon, Isabelle Fouchard-Hubert, Dominique Larrey, Manh Thông Dao, Louis d'Alteroche, Nathalie Boyer-Darrigand, Nicolas Picard, Hélène Le Guillou-Guillemette, Patrick Saulnier, Alexandra Ducancelle, et al.

\section{To cite this version:}

Pascal Veillon, Isabelle Fouchard-Hubert, Dominique Larrey, Manh Thông Dao, Louis d'Alteroche, et al.. Does Epoetin Beta Still Have a Place in Peginterferon Alpha-2a Plus Ribavirin Treatment Strategies for Chronic Hepatitis C?. Journal of Interferon and Cytokine Research, 2016, 36 (3), pp.204-214. 10.1089/jir.2015.0131 . hal-01392291

\section{HAL Id: hal-01392291 \\ https://hal.science/hal-01392291}

Submitted on 8 Oct 2021

HAL is a multi-disciplinary open access archive for the deposit and dissemination of scientific research documents, whether they are published or not. The documents may come from teaching and research institutions in France or abroad, or from public or private research centers.
L'archive ouverte pluridisciplinaire HAL, est destinée au dépôt et à la diffusion de documents scientifiques de niveau recherche, publiés ou non, émanant des établissements d'enseignement et de recherche français ou étrangers, des laboratoires publics ou privés. 


\title{
Does Epoetin Beta Still Have a Place in Peginterferon Alpha-2a Plus Ribavirin Treatment Strategies for Chronic Hepatitis C?
}

\author{
Pascal Veillon, ${ }^{1,2}$ Isabelle Fouchard-Hubert, ${ }^{2,3}$ Dominique Larrey, ${ }^{4}$ Manh Thông Dao, ${ }^{5}$ Louis D'alteroche, ${ }^{6}$ \\ Nathalie Boyer-Darrigand, ${ }^{7}$ Nicolas Picard, ${ }^{8}$ Hélène Le Guillou-Guillemette, ${ }^{1,2}$ Patrick Saulnier, ${ }^{9}$ \\ Alexandra Ducancelle, ${ }^{1,2}$ Véronique Loustaud-Ratti, ${ }^{10}$ and Françoise Lunel-Fabiani ${ }^{1,2}$
}

To investigate the impact of epoetin beta (EPO) on sustained virological response (SVR) in hepatitis C virus (HCV)infected patients treated with peginterferon-ribavirin (RBV). Controlled, randomized, pragmatic multicenter study to assess 2 strategies, ie, the use (EPO group) or nonuse (control group) of EPO in terms of achieving SVR in treatment-naive, genotype non-2/non-3 HCV-infected patients receiving a 48-week treatment regimen of pegylated interferon $\alpha$-2a (peg-IFN) plus RBV (randomization 2:1). The single-nucleotide polymorphisms of interferon lambda 3 (IFNL3) (rs12979860 and rs8099917), interferon lambda 4 (IFNL4) (ss469415590), and inosine triphosphatase (ITPA) (rs1127354 and rs7270101) were determined retrospectively. Two hundred twenty-seven patients were included in the study. In the global population $(n=227)$, the overall SVR rate was $52 \%(118 / 227)$. Nonresponse and relapse occurred in respectively 46/227 (20.3\%) and 42/227 (18.5\%) patients. In the intention-to-treat analysis, $55.5 \%$ of patients with anemia $(n=164)$ had a SVR, specifically $57.4 \%$ in the EPO group versus $52.4 \%$ in the control group, but the difference was not statistically significant. In the anemic population, independent factors associated with SVR were IFNL3 and IFNL4 polymorphisms, pretreatment HCV RNA level, iron level, and aspartate aminotransferase/alanine aminotransferase (AST/ALT) ratio. EPO has little impact on SVR in patients treated with peg-IFN+RBV and should be recommended only for patients with severe anemia.

\section{Introduction}

$\mathrm{H}$ EPATITIS C VIRUS (HCV) infection is a major cause of morbidity and mortality, affecting 150 million people worldwide (Lavanchy 2009). In France, in 2004, there were 368,000 people affected by the disease, among these 221,000 were RNA positive (Meffre and others 2010). Extended studies of the natural history of HCV disease have shown that chronic infection is associated with an increased risk of complications, including cirrhosis, hepatic decompensation, and hepatocellular carcinoma. Starting in 1986, treatment consisted initially of interferon (IFN) alone (Hoofnagle and others 1986; Di Bisceglie and others 1990), which was later combined with ribavirin (RBV) (Hoofnagle and others 1986; Di Bisceglie and others 1990). Pegylated interferon-alfa (peg-IFN) plus RBV was introduced in 2000 and this combination has been providing viral eradication in $40 \%-45 \%$ of patients infected with HCV genotype 1 and in $80 \%$ of patients infected with HCV genotypes 2 or 3 (Manns and others 2001; Reddy and others 2001; Fried and others 2002; Hadziyannis and others 2003).

In 2011, new direct-acting antiviral agents (DAAs), ie, protease inhibitors such as telaprevir and boceprevir, were approved in Europe and the United States for the treatment of patients infected with genotype 1 . These first-generation DAAs provide sustained virological response (SVR) rates as high as $61 \%-69 \%$, but at the cost of numerous adverse events (McHutchison and others 2009; Kwo and others 2010). New

\footnotetext{
${ }^{1}$ Department of Virology, University Hospital of Angers, Angers, France.

${ }^{2}$ HIFIH Research Unit, Faculty of Medicine, UPRES 3859, SFR 4208, University of Angers, Angers, France.

${ }^{3}$ Department of Hepatology and Gastroenterology, University Hospital of Angers, Angers, France.

${ }^{4}$ Department of Hepatology and Transplantation, University Hospital of Montpellier, Montpellier, France.

${ }^{5}$ Gastroenterology and Nutrition, University Hospital of Caen, Caen, France.

${ }^{6}$ Department of Hepatology and Gastroenterology, University Hospital of Tours, Chambray-les-Tours, France.

${ }^{7}$ Department of Hepatology, Physiopathology and Treatment of Viral Hepatitis, Hospital of Beaujon, Clichy, France.

${ }^{8}$ INSERM UMR-850, Department of Pharmacology, Toxicology and Pharmacovigilance, University Hospital of Limoges, Limoges, France.

${ }^{9}$ Micro and Nanomedecines biomimetics, INSERM UMRS 1066, University of Angers, Angers, France.

${ }^{10}$ Department of Hepatology and Gastroenterology, University Hospital of Limoges, INSERM UMR 1092, Limoges, France.
} 
second-generation DAAs have been approved or are pending approval (ie, sofosbuvir, simeprevir, daclatasvir, ledipasvir, paritaprevir/ritonavir, ombitasvir, and dasabuvir) in the United States and Europe. However, these DAAs are very expensive, and thus, peg-IFN+RBV remains the standard of care (SOC) in many, particularly developing, countries around the world.

Under peg-IFN and RBV therapy, the SVR rate decreases dramatically when adherence to treatment is not optimal (McHutchison and others 2002). Adverse events are the main cause of poor compliance, and among them, dosedependent hemolytic anemia induced by RBV stands out, as it causes dose reductions or early withdrawal in 10\%-20\% of patients (Dieterich and others 2003; Hadziyannis and others 2003; Afdhal and others 2004). Thus, to achieve a SVR and ultimately avoid long-term complications of HCV infection, improving therapeutic compliance is a priority.

Viral genotype and pretreatment HCV RNA viral load and its decline under treatment, age, ethnicity, and fibrosis stage are the main predicting factors of response to peg-IFN+RBV therapy. Recently, a genome-wide association study demonstrated an association between genetic variants and treatment response. Of the single-nucleotide polymorphisms (SNPs) studied, there were 2 (rs12979860 and rs8099917) located near the interferon lambda 3 (IFNL3) gene region (previously known as the IL28B gene region) that were strongly associated with treatment response in patients infected with genotype 1 (Ge and others 2009; Suppiah and others 2009; Tanaka and others 2009). This association was also observed later in patients infected with genotype 4 (Jimenez-Sousa and others 2013).

Evolving experience and recent clinical trials indicate that the use of hematopoietic growth factors, particularly epoetin beta (EPO), during HCV treatment with peg-IFN+RBV may permit the maintenance of optimal dose and duration and furthermore improve patient quality of life (Pockros and others 2004; Lebray and others 2005; Chapko and Dominitz 2006). The authors of a meta-analysis performed in 2011 concluded that EPO administration in patients who develop anemia can considerably enhance SVR (Alavian and others 2012). However, controlled studies comparing currently recommended standard treatment with or without EPO have not been performed (Talal and others 2001). This most likely explains why no official guidelines exist for treating anti-HCV therapyassociated anemia, and many issues remain unresolved.

The aim of the present study was to evaluate prospectively the impact of EPO on SVR in anemic patients treated with peg-IFN+RBV.

\section{Patients and Methods}

\section{Study design}

We conducted a national, prospective, randomized, controlled phase $3 \mathrm{~b}$ study in 31 French hospital centers between November 2007 and June 2009 (clinicaltrials.gov No. NTC00262379) to determine the impact of complementary EPO on SVR in treatment-naive, genotype non-2/non-3 $\mathrm{HCV}$-infected patients who experienced anemia under pegIFN+RBV treatment. The determination of host IFN polymorphisms was performed retrospectively after the initial publication by Ge and others. A specific signed consent form approved by local and national ethical committees was obtained. Our aim in gathering this information was to exclude a disequilibrium of these genetic variants between the 2 groups, which might have introduced a bias in the analysis ( $\mathrm{Ge}$ and others 2009).

As EPO is efficient in preventing anemia during pegIFN+RBV therapy, our trial was constructed as a pragmatic study with the goal of determining whether or not EPO should be used to increase SVR during peg-IFN and RBV therapy: $\alpha$ risk and $\beta$-risk of respectively $100 \%$ and $0 \%$ were used (Schwartz and Lellouch 2009). We hypothesized a 15\% difference in SVR between the experimental (with EPO) and control (without EPO) groups, ie, $65 \%$ for the former and $50 \%$ for the latter. For a $\gamma$-risk of 5\% (error in the choice of the good strategy), the number of patients needed to conclude was 60 in each group. However, based on the article by Balan and others (2005), we expected that $50 \%$ of the patients would not meet the criteria to receive EPO. For this reason, we doubled the number of patients to be included in the EPO group (thus 60 patients in the control group and 120 patients in the EPO group). We also estimated first that $10 \%$ of the patients would not experience anemia during treatment and secondarily that $10 \%$ of the patients would have a major deviation from protocol and/or be lost to follow-up. Finally, the total number of patients included in the study was 222. Patients were $1: 2$ randomized to the control group or EPO group at inclusion.

\section{Patients}

Patients aged more than 18 years, infected with genotype 1, 4, 5, or $6 \mathrm{HCV}$, and presenting detectable HCV RNA were included. They had compensated liver disease (ChildPugh $\leq 6)$ and were naive of treatment. Patients with HIV or HBV coinfection or hepatocellular carcinoma were excluded from the study as were those who had received EPO in the 2 months before the start of HCV treatment. The pegIFN $\alpha-2 a$ and RBV therapy was conducted as per French recommendations (ANAES 2002). All patients provided signed informed consent.

\section{Treatment regimen and follow-up}

All patients were treated with SOC: peg-IFN $\alpha$-2a $180 \mu \mathrm{g}$ weekly plus RBV 1,000-1,200 mg daily for 48 weeks. EPO $(30,000 \mathrm{U}$ weekly) was added to the SOC in the EPO group when the hemoglobin $(\mathrm{Hb})$ level defined anemia, ie, below $12 \mathrm{~g} / \mathrm{dL}$ in men and below $11 \mathrm{~g} / \mathrm{dL}$ in women. EPO administration was 30,000 IU subcutaneously once per week for an initial period of 4 weeks. After this first period, if the $\mathrm{Hb}$ level increased more than $2 \mathrm{~g} / \mathrm{dL}$, the EPO dosage was decreased by at least $25 \%$, if the $\mathrm{Hb}$ level increased between 1 and $2 \mathrm{~g} / \mathrm{dL}$, the EPO was maintained at 30,000 IU weekly, and if the $\mathrm{Hb}$ level did not increase to at least $1 \mathrm{~g} / \mathrm{dL}$, the EPO was increased to 60,000 IU weekly for another 4 weeks. The Hb level was reevaluated after this second 4 -week period. If there was no response, the EPO was stopped. In all cases, the $\mathrm{Hb}$ level had to be maintained under $13 \mathrm{~g} / \mathrm{dL}$ (French recommendation at the beginning of the trial, http://ansm.sante.fr/). The intention-totreat (ITT) analysis considered patients who presented anemia (as defined above) during treatment. A per protocol analysis was also performed in patients who received $48 \pm 4$ weeks of the peg-IFN+RBV therapy.

\section{Clinical endpoints}

Our primary endpoint was SVR, defined as undetectable HCV RNA 24 weeks after the end of treatment (EOT). 
Secondary endpoints were quality of life estimated by the Short Form Health Survey 36 Items (SF-36), Hepatitis Quality of Life Questionnaire (HQLQ) questionnaires, fatigue severity scale (FSS), a visual analog scale, and the cumulative dose of RBV between 0 and 24 weeks (Bayliss and others 1998; Dalgard and others 2004).

\section{Clinical and laboratory assessments}

Hematological parameters, platelet count, aspartate aminotransferase (AST), and alanine aminotransferase (ALT) were assessed at baseline, then at weeks 2 and 4, then every 4 weeks until EOT, and during the posttreatment period at weeks 52, 60, and 72. HCV RNA levels were determined at baseline and after 12, 24, and 48 weeks of treatment, and at week 72, 6 months after the EOT.

IFNL3, interferon lambda 4 (IFNL4) and inosine triphosphatase (ITPA) polymorphisms were determined retrospectively using genomic DNA obtained from peripheral blood mononuclear cells or saliva after obtaining specific signed informed consent. Genomic DNA was extracted with the easyMAG automated system (BioMerieux) from peripheral blood mononuclear cells. Saliva was collected with the ORAGENE OG-500 DNA Collection Kit (DNA Genotek, Inc.), and genomic DNA extraction performed according to the manufacturer's precipitation protocol or with the MN plasma XS kit (Macherey Nagel) (Witt and others 2012). Genotyping of IFNL3 SNPs rs12979860 and rs8099917 was performed by pyrosequencing using 2 specific primers for each SNP. This method is based on luminometric detection of pyrophosphate released upon nucleotide incorporation during DNA synthesis. The reaction generates a flash recorded as a peak in a program (Ronaghi 2001; Royo and others 2009). IFNL4 and ITPA genotyping was performed using TaqMan real-time polymerase chain reaction (PCR) discrimination assays (Life Technologies) with the Type-it Fast Probe PCR Master Mix (Qiagen) and the Rotor-Gene Q PCR instrument (Qiagen). PCRs were performed in 100-well Rotor-Disc (Qiagen) rotors. The reaction mixture $(10 \mu \mathrm{L})$ contained $5 \mu \mathrm{L}$ of genomic DNA $(2 \mathrm{ng} / \mu \mathrm{L})$ and $5 \mu \mathrm{L}$ of master mix and the SNP assay. Each SNP assay contained 2 primers for amplifying the sequence of interest and 2 TaqMan probes for detecting alleles. ITPA SNP assays were ordered from Life Technologies as functionally tested assays (references C_ 27465000_10 and C__29168507_10 for rs1127354 and ITPA-rs7270101, respectively). IFNL4-ss469415590 assay was a custom TaqMan genotyping assay (Assay ID: AHRSOBV; forward primer: GCCTGCTGCAGAAGCAGAGAT, reverse primer: GCTC CAGCGAGCGGTAGTG, VIC-Reporter: ATCGCAGAAG GCC, FAM-reporter: ATCGCAGCGGCCC).

Genotypes were defined as follows: IFLN3-rs12979860: CC, CT, or TT (minor allele = T); IFNL3-rs8099917: TT, TG, or GG (minor allele $=\mathrm{G}$ ) and IFNL4-ss469415590: TT/ TT or G carriers; ITPA-rs1127354: CC, CA, or AA (minor allele $=\mathrm{A}$ ) and ITPA-rs7270101: AA, AC, or CC (minor allele $=\mathrm{C}$ ). Genotype distributions conformed to the HardyWeinberg equilibrium (chi-square test $P>0.05$ ).

Liver fibrosis was assessed with liver biopsy, transient elastometry, fibrotest, or fibrometer when data were available in each investigation center and we calculated aspartate aminotransferase to platelet ratio index (APRI) and Fibrosis 4 score (FIB-4) scores retrospectively for all patients. For homogenization of the data, the severity of fibrosis was classified as clinically significant fibrosis (CSF) and no CSF and cirrhosis or no cirrhosis. No CSF was defined by an APRI score $\leq 0.5$ and CSF by an APRI $\geq 1.5$; no cirrhosis was defined by an APRI $\leq 1.0$ and cirrhosis by an APRI $\geq 2.0$. In parallel, FIB-4 was used to determine no severe fibrosis (FIB-4 $\leq 1.5$ ) or severe fibrosis (FIB-4 $\geq 3.25$ ) (Wai and others 2003; Sterling and others 2006). The severity of fibrosis was established, secondarily, according to available results from liver biopsy staging, transient elastometry, fibrometer, and fibrotest.

\section{Statistical analysis}

Quantitative data are described by means or medians with standard deviations or $95 \%$ confidence intervals. Group comparisons of categorical variables were performed using the Pearson chi-square test or Fisher's exact test. To compare numerical variables, the Student's $t$-test or Mann-Whitney Utest were used when appropriate. Multivariate logistic regressions by forward stepwise analysis were performed with SVR or anemia as the dependent variable and were evaluated using several statistical tests (mainly log-likelihood ratio test and the Hosmer-Lemeshow test). Multivariate analysis was split in 2 ways, with or without SNPs. To compare the performance of the logistic regression models, StAR software was used to plot receiver operator curves (ROCs) and perform statistical comparisons of the area under the curve (AUC) of each ROC (Vergara and others 2008). Statistical analysis was performed with SPSS software version 15 (SPSS, Inc.). A 2-sided P value of 0.05 was considered statistically significant.

\section{Results}

\section{Population characteristics and virological response}

Figure 1 provides a flowchart of the trial and Tables 1 and 2 the characteristics of the global and ITT (anemic patients) patient populations, respectively. No significant differences were observed between the EPO and control groups. Considering all patients $(n=227), 17.2 \%$ had cirrhosis. The overall rate of SVR in all patients $(52 \%)$ was similar to that found in previous studies on peg-IFN+RBV treatment. Interestingly, only 46 patients $(20.3 \%)$ did not respond, $42(18.5 \%)$ relapsed after treatment, and $5(2.2 \%)$ had a breakthrough (Table 3$)$. In the ITT population $(n=164)$, SVR was obtained in 91 patients $(55.5 \%)$, with a slightly higher rate in the EPO group (57.4\%) than in the control group $(52.4 \%)$, but the difference was not statistically significant (Table 3 ). A comparable difference was observed in the per protocol analysis $(60.3 \%$ versus $55.8 \%$, NS). The retrospectively calculated gamma-risks were $26.6 \%$ and $31.0 \%$ in the ITT and per protocol analyses, respectively. According to HCV genotype, we noticed a close rate of SVR for genotypes 1 and $4(53.0 \%$ and $51.4 \%$, respectively).

\section{EPO prescription and $R B V$ dose reduction}

Overall, 82 of $149(55.0 \%)$ patients received EPO, and 18 of $82(22.0 \%)$ received a dose of 60,000 IU/week during antiviral treatment. For all patients, during the first 24 weeks of treatment, RBV dose reduction was observed in $24.7 \%$ of the patients in the control group (19/77) versus $9.5 \%$ of those in the EPO group $(14 / 148)(P=0.004)$. RBV discontinuation was observed in $10.5 \%$ of the control patients $(8 / 76)$ and in $14.2 \%$ of the EPO patients $(21 / 148)(P=0.53)$. The 


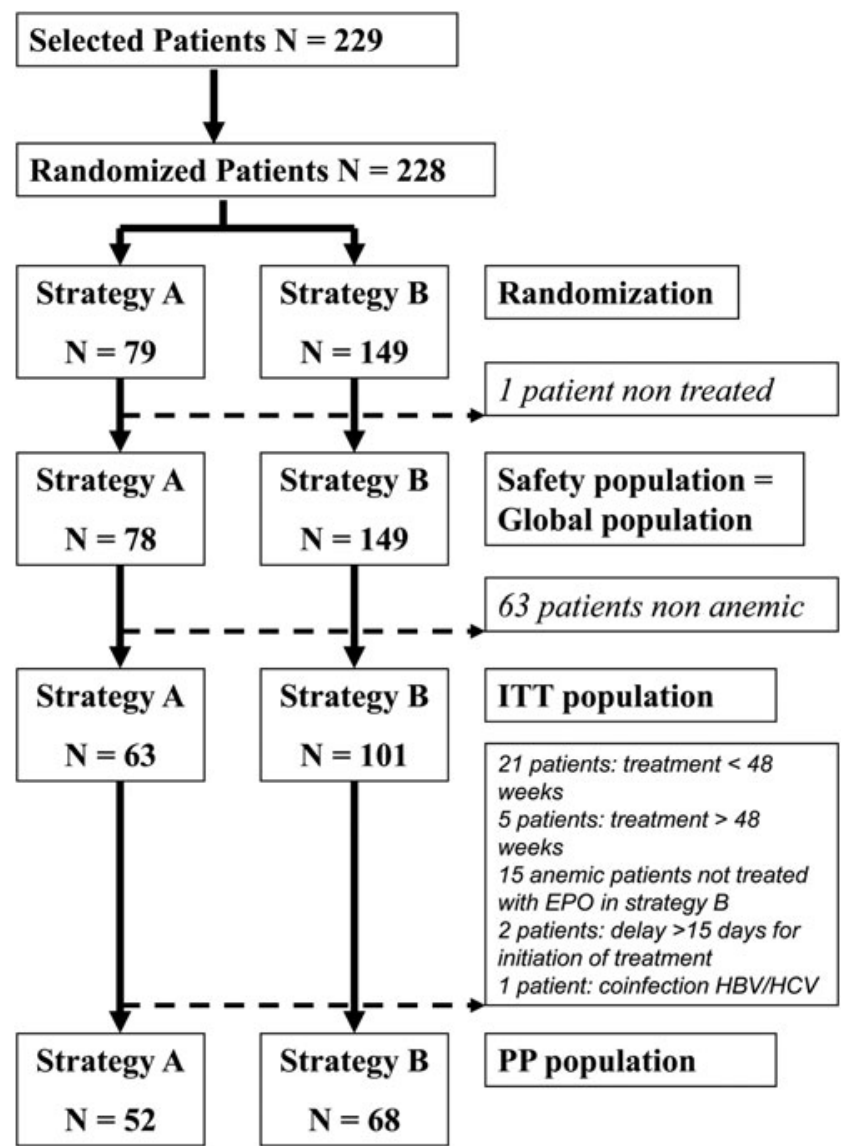

FIG. 1. Flow chart. Strategy A: no EPO treatment. Strategy B: EPO treatment. EPO, epoetin beta.

cumulative doses of RBV, at week 24, were not different between the control and EPO groups, respectively, 2,329.1 \pm 532.9 and $2,337.3 \pm 588.1 \mathrm{mg} / \mathrm{kg}(P=0.97$, Table 4$)$.

In the ITT population, RBV dose reduction was statistically higher in the control group [27.4\% (17/61) versus $13 \%$ (13/100) in the EPO group, $P=0.036]$ but not RBV discontinuation [11.5\% (7/61) versus $10 \%$ (10/100), $P=0.79$ ]. The cumulative dose of RBV, at week 24 , was higher in the EPO group, but the difference was not statistically significant (control group: 2,321.2 $\pm 584.2 \mathrm{mg} / \mathrm{kg}$ versus EPO group: $2,455.7 \pm 530.3 \mathrm{mg} / \mathrm{kg}, P=0.34$, Table 4 ).

We found no differences between the control and EPO groups regarding the cumulative doses of RBV at weeks 8 , 12, and 48 (Table 4).

\section{Adverse events}

The rate of adverse clinical events was more than $95.6 \%$ for all patients, with asthenia (56.4\%), insomnia (37.9\%), and pruritus $(30.8 \%)$ being the most frequent (Table 5). Asthenia was more frequent in the EPO group than in the control group (respectively, $64.6 \%$ versus $51.7 \%$ ), as were insomnia and pruritus $(35.4 \%$ versus $28.3 \%$ and $39.0 \%$ versus $37.2 \%$ ). In contrast, dyspnea was significant less frequent in patients who received EPO (11.0\%) than in those who did not $(22.0 \%)$ $(P<0.04)$. Sixty-three of the $78(80.8 \%)$ patients included in the control group presented an anemia as defined in our protocol $(\mathrm{Hb}<11 \mathrm{~g} / \mathrm{dL}$ for women and $<12 \mathrm{~g} / \mathrm{dL}$ for men) and would have normally received EPO.
Table 1. Baseline Characteristics of Patients

\begin{tabular}{|c|c|c|c|c|}
\hline & $\begin{array}{c}\text { All } \\
\text { patients } \\
(\mathrm{n}=227)\end{array}$ & $\begin{array}{c}\text { Control } \\
\text { group } \\
(\mathrm{n}=78)\end{array}$ & $\begin{array}{c}\text { EPO } \\
\text { group } \\
(\mathrm{n}=149)\end{array}$ & $\mathrm{P}$ value \\
\hline Age (years) & $48.8 \pm 12.4$ & $49.7 \pm 11.3$ & $48.3 \pm 13.0$ & 0.45 \\
\hline $\begin{array}{l}\text { Sex (male/ } \\
\text { female) }\end{array}$ & $138 / 89$ & $49 / 29$ & $89 / 60$ & 0.67 \\
\hline Weight (kg) & $72.4 \pm 14.9$ & $73.1 \pm 12.4$ & $72.0 \pm 15.4$ & 0.62 \\
\hline Height $(\mathrm{cm})$ & $170.2 \pm 9.2$ & $170.4 \pm 8.5$ & $170.1 \pm 9.6$ & 0.80 \\
\hline $\mathrm{Hb}(\mathrm{g} / \mathrm{dL})$ & $14.66 \pm 1.31$ & $14.70 \pm 1.41$ & $14.64 \pm 1.25$ & 0.92 \\
\hline Platelets $(\mathrm{g} / \mathrm{L})$ & $226.7 \pm 75.7$ & $219.7 \pm 75.4$ & $228.8 \pm 76.0$ & 0.52 \\
\hline AST (U/L) & $66.8 \pm 52.8$ & $64.8 \pm 48.1$ & $67.8 \pm 55.2$ & 0.53 \\
\hline ALT (U/L) & $96.4 \pm 76.8$ & $95.4 \pm 69.7$ & $96.9 \pm 80.4$ & 0.25 \\
\hline $\begin{array}{c}\text { Baseline HCV } \\
\text { RNA (log } \\
\text { IU/mL) }\end{array}$ & $5.92 \pm 0.73$ & $5.98 \pm 0.72$ & $5.88 \pm 0.73$ & 0.38 \\
\hline \multicolumn{5}{|l|}{ Genotype } \\
\hline $1(\%)$ & $185(81.5)$ & $66(84.6)$ & 119 (79.9) & \multirow[t]{4}{*}{0.65} \\
\hline $4(\%)$ & 35 (15.4) & $11(14.1)$ & $24(16.1)$ & \\
\hline $5(\%)$ & $6(2.6)$ & $1(1.3)$ & $5(3.4)$ & \\
\hline $3(\%)$ & $1(0.5)$ & - & $1(0.7)$ & \\
\hline Cirrhosis, $n(\%)$ & $39(17.2)$ & $16(20.5)$ & $23(15.4)$ & \multirow{4}{*}{$\begin{array}{r}0.36 \\
>0.99\end{array}$} \\
\hline $\begin{array}{l}\text { rs12979860 } \\
\text { CC }\end{array}$ & & & & \\
\hline $\mathrm{CC}$ & 30 & 12 & 18 & \\
\hline non-CC & 70 & 27 & 43 & \\
\hline rs8099917 & & & & \multirow[t]{3}{*}{0.84} \\
\hline TT & 51 & 21 & 30 & \\
\hline non-TT & 48 & 18 & 30 & \\
\hline ss469415590 & & & & \multirow[t]{3}{*}{0.35} \\
\hline TT/TT & 25 & 12 & 13 & \\
\hline$\Delta \mathrm{G}$ carriers & 73 & 27 & 46 & \\
\hline rs 1127354 & & & & \multirow[t]{3}{*}{0.09} \\
\hline $\mathrm{CC}$ & 83 & 36 & 47 & \\
\hline non-CC & 16 & 3 & 13 & \\
\hline rs7270101 & & & & \multirow[t]{3}{*}{0.15} \\
\hline AA & 75 & 33 & 42 & \\
\hline non-AA & 24 & 6 & 18 & \\
\hline
\end{tabular}

Results are shown as mean \pm SD.

EPO, epoetin beta; Hb, hemoglobin; AST, aspartate aminotransferase; ALT, alanine aminotransferase; HCV, hepatitis C virus; SD, standard deviation.

Few adverse events possibly attributable to EPO were observed in this trial. They were headache in 3 patients, hypertension in 2 patients, rash in 2 patients, malaise in 1 patient, and lithium overdose in 1 patient (the only serious adverse event due to EPO).

\section{Predictive factors of SVR}

In univariate analysis, age, pretreatment HCV RNA level, HCV RNA decline $\geq 2 \log \mathrm{IU} / \mathrm{mL}$ at 12 weeks, fibrosis stage assessed by blood scores (fibrometer, FIB-4 score) or transient elastometry, $\gamma$-glutamyl transferase (GGT), platelets, iron, ferritin, vitamin B12, alkaline phosphatases, albumin, alpha-2 macroglobulin, alpha-fetoprotein levels, and the 2 polymorphisms ss469415590 and rs12979860 were all associated with SVR. In the global population, when SNP polymorphisms were not considered, multivariate analysis identified pretreatment HCV RNA level, GGT, and the AST/ALT ratio as being predictive for SVR. When host genetic factors were considered, pretreatment HCV RNA level, the dinucleotide ss469415590 (but not rs12979860), and the absence of clinically significantly fibrosis were predictive for SVR (Table 6). In the ITT population, independent predictors of SVR were pretreatment HCV RNA, 
Table 2. Baseline Characteristics of THE INTENTION-TO-TREAT POPUlation

\begin{tabular}{|c|c|c|c|c|}
\hline & $\begin{array}{c}\text { All } \\
\text { patients } \\
(\mathrm{n}=164)\end{array}$ & $\begin{array}{l}\text { Control } \\
\text { group } \\
(\mathrm{n}=63)\end{array}$ & $\begin{array}{c}\text { EPO } \\
\text { group } \\
(\mathrm{n}=101)\end{array}$ & $\mathrm{P}$ value \\
\hline Age (years) & $51.7 \pm 11.6$ & $52.3 \pm 10.5$ & $51.4 \pm 12.2$ & 0.61 \\
\hline Sex (male/female) & $96 / 68$ & $40 / 23$ & $56 / 45$ & 0.33 \\
\hline Weight $(\mathrm{kg})$ & $71.1 \pm 14.8$ & $72.4 \pm 13.7$ & $70.2 \pm 15.5$ & 0.37 \\
\hline Height $(\mathrm{cm})$ & $169.5 \pm 9.4$ & $171.0 \pm 8.8$ & $168.5 \pm 9.6$ & 0.11 \\
\hline $\mathrm{Hb}(\mathrm{g} / \mathrm{dL})$ & $14.52 \pm 1.33$ & $14.62 \pm 1.40$ & $14.45 \pm 1.29$ & 0.43 \\
\hline Platelets $(\mathrm{g} / \mathrm{L})$ & $217.7 \pm 66.4$ & $211.5 \pm 63.9$ & $221.6 \pm 67.9$ & 0.34 \\
\hline AST (U/L) & $67.1 \pm 49.5$ & $72.9 \pm 51.4$ & $63.5 \pm 48.2$ & 0.24 \\
\hline ALT (U/L) & $94.9 \pm 76.7$ & $108.0 \pm 91.4$ & $86.8 \pm 65.0$ & 0.11 \\
\hline $\begin{array}{c}\text { Baseline HCV } \\
\text { RNA (log } \\
\text { IU/mL) }\end{array}$ & $5.93 \pm 0.75$ & $5.98 \pm 0.73$ & $5.90 \pm 0.76$ & 0.52 \\
\hline Genotype & & & & 0.98 \\
\hline $1(\%)$ & $135(82.3)$ & $52(82.5)$ & $83(82.2)$ & \\
\hline $4(\%)$ & $26(15.9)$ & $10(15.9)$ & $16(15.8)$ & \\
\hline $5(\%)$ & $3(1.8)$ & $1(1.6)$ & $2(2.0)$ & \\
\hline Cirrhosis, $n(\%)$ & 31 (18.9) & $14(22.2)$ & $17(16.8)$ & 0.42 \\
\hline $\begin{array}{l}\text { rs } 12979860 \\
\text { CC }\end{array}$ & 25 & 11 & 14 & $>0.99$ \\
\hline non-CC & 52 & 23 & 29 & \\
\hline rs8099917 & & & & 0.49 \\
\hline TT & 41 & 20 & 21 & \\
\hline non-TT & 35 & 14 & 21 & \\
\hline ss469415590 & & & & 0.61 \\
\hline TT/TT & 21 & 11 & 10 & \\
\hline$\Delta \mathrm{G}$ carriers & 54 & 23 & 31 & \\
\hline rs1127354 & & & & 0.21 \\
\hline $\mathrm{CC}$ & 64 & 31 & 33 & \\
\hline non-CC & 12 & 3 & 9 & \\
\hline rs7270101 & & & & 0.02 \\
\hline AA & 60 & 31 & 29 & \\
\hline non-AA & 16 & 3 & 13 & \\
\hline
\end{tabular}

Results are shown as mean \pm SD.

iron level, and AST/ALT ratio when host genetic markers were excluded and pretreatment HCV RNA, iron level, and the dinucleotide ss469415590 when host genetic markers were included (Table 6). The AUCs of the models in the global and ITT populations were higher with ss469415590

Table 3. Virological Response in the Global AND INTENTION-TO-TREAT POPUlations

\begin{tabular}{lccccc}
\hline Global population & $N R$ & $B T$ & $R R$ & $S V R$ & $L C, A E$ \\
\hline All patients & 46 & 5 & 42 & 118 & 16 \\
$n=227$ & $20.3 \%$ & $2.2 \%$ & $18.5 \%$ & $52.0 \%$ & $7.0 \%$ \\
Control group & 18 & 2 & 14 & 40 & 4 \\
$n=78$ & $23.1 \%$ & $2.6 \%$ & $17.9 \%$ & $51.3 \%$ & $5.1 \%$ \\
EPO group & 28 & 3 & 28 & 78 & 12 \\
$n=149$ & $18.8 \%$ & $2.0 \%$ & $18.8 \%$ & $52.3 \%$ & $8.1 \%$ \\
\hline ITT population & $N R$ & $B T$ & $R R$ & $S V R$ & $L C, A E$ \\
\hline All patients & 28 & 3 & 35 & 91 & 7 \\
$n=164$ & $17.1 \%$ & $1.8 \%$ & $21.3 \%$ & $55.5 \%$ & $4.3 \%$ \\
Control group & 12 & 2 & 13 & 33 & 3 \\
$n=63$ & $19.0 \%$ & $3.2 \%$ & $20.6 \%$ & $52.4 \%$ & $4.8 \%$ \\
EPO group & 16 & 1 & 22 & 58 & 7 \\
$n=101$ & $15.8 \%$ & $1.0 \%$ & $21.8 \%$ & $57.4 \%$ & $4.0 \%$ \\
\hline
\end{tabular}

NR, nonresponders; BT, breakthrough; RR, responders-relapsers; SVR, sustained virological response; LC, lost to contact; AE, adverse event; ITT, intention-to-treat.
Table 4. Ribavirin Dose Intake by Patients at Different Steps of Treatment

\begin{tabular}{lcrrr}
\hline Week & Population & Control group & EPO group & P value \\
\hline 8 & GP & $823.3 \pm 128.4$ & $831.9 \pm 151.0$ & 0.953 \\
& ITT & $829.6 \pm 136.7$ & $851.8 \pm 160.7$ & 0.591 \\
12 & GP & $1,216.5 \pm 201.9$ & $1,221.0 \pm 245.2$ & 0.718 \\
& ITT & $1,221.2 \pm 227.2$ & $1,264.0 \pm 248.2$ & 0.533 \\
24 & GP & $2,329.1 \pm 532.9$ & $2,337.3 \pm 588.1$ & 0.966 \\
& ITT & $2,321.2 \pm 584.2$ & $2,455.7 \pm 530.3$ & 0.344 \\
48 & GP & $4,261.8 \pm 1,498.2$ & $4,233.9 \pm 1,533.4$ & 0.731 \\
& ITT & $4,260.2 \pm 1,555.9$ & $4,530.9 \pm 1,414.0$ & 0.522
\end{tabular}

GP, global population.

than with rs12979860 ( 0.825 versus 0.801 and 0.833 versus 0.820 , respectively); no significant differences between the 2 AUCs obtained for each population were observed (global population, $P=0.15$, and ITT population, $P=0.42$ ).

Interestingly, in our study, $100 \%$ of our patients $(11 / 11)$ with favorable genetic polymorphisms (IFNL4 or IFNL3) and viral loads $<800,000 \mathrm{IU} / \mathrm{mL}$ had SVRs.

\section{Predictive factors of anemia during treatment and at week 4}

We searched for predictive factors of anemia during treatment and at week 4 in the global and ITT populations. In univariate analysis, age, $\mathrm{Hb}$ level, red and white cell counts, neutrophil count, platelet count, creatinine, haptoglobin level, alpha-2 macroglobulin level, FIB-4 score, and ITPA rs1127354 were associated with anemia during treatment or at week 4. In multivariate analysis, the only independent factors associated with anemia during treatment were age and baseline $\mathrm{Hb}$ level in the global population, with no impact for ITPA rs1127354 (Table 7). Independent factors associated with onset of anemia at week 4 were red blood cell count, creatinine, haptoglobin, and the baseline $\mathrm{Hb}$ level; no impact for ITPA rs1127354 was observed (Table 7).

\section{Quality of life}

We did not observe marked differences between the control and EPO groups regarding quality of life during treatment (Fig. 2, no comparisons were significantly different). Surprisingly, in both the global and ITT populations during treatment (week 24), control patients felt better than EPO patients regarding bodily pain and mental health (SF36 components), and in the global population, only they felt better for vitality and social functioning.

\section{Discussion}

DAA regimens free of IFN and RBV have transformed the therapeutic landscape for chronic hepatitis $\mathrm{C}$, but their current cost makes them accessible only when significant financial means are available. Thus, in many countries, pegIFN+RBV remains the SOC today. Previous clinical studies have pointed out that adherence to therapy, and particularly to RBV, was crucial for treatment efficacy, thus maintaining the initial RBV dosage may be useful for achieving viral clearance (Fried and others 2002; McHutchison and others 2002). Indeed, previous studies have shown that RBV is a key tool for hepatitis $\mathrm{C}$ treatment, working synergistically with peg-IFN to double the response obtained with this latter 
Table 5. Adverse Events According to Epoetin Beta Intake

\begin{tabular}{lrrrr}
\hline Events & \multicolumn{1}{c}{ All patients } & No EPO intake & EPO intake & P value \\
\hline All events/patients (\%) & $1,969 / 217(95.6)$ & $1,196 / 136(93.8)$ & $773 / 81(98.8)$ & \\
Asthenia & $170 / 128(56.4)$ & $102 / 75(51.7)$ & $68 / 53(64.6)$ & $<0.40$ \\
Influenza-like illness & $47 / 46(26.0)$ & $37 / 33(22.8)$ & $27 / 26(31.7)$ & $<0.22$ \\
Irritability & $47 / 46(20.3)$ & $32 / 31(21.4)$ & $15 / 15(18.3)$ & $<0.46$ \\
Fatigue & $35 / 34(15.0)$ & $22 / 22(15.2)$ & $13 / 12(14.6)$ & $<0.80$ \\
Pruritus & $86 / 70(30.8)$ & $48 / 41(28.3)$ & $38 / 29(35.4)$ & 0.39 \\
Dry skin & $44 / 40(17.6)$ & $30 / 28(19.3)$ & $14 / 12(14.6)$ & $<0.29$ \\
Alopecia & $35 / 34(15.0)$ & $19 / 19(13.1)$ & $16 / 15(18.3)$ & $<0.38$ \\
Nausea & $39 / 38(16.7)$ & $21 / 21(14.5)$ & $18 / 17(20.7)$ & $<0.30$ \\
Insomnia & $95 / 86(37.9)$ & $61 / 54(37.2)$ & $34 / 32(39.0)$ & $<0.99$ \\
Cough & $45 / 43(18.9)$ & $31 / 30(20.7)$ & $14 / 13(15.9)$ & $<0.70$ \\
Dyspnea & $38 / 34(15.0)$ & $19 / 16(11.0)$ & $19 / 18(22.0)$ & $<0.05$ \\
Headache & $59 / 55(24.2)$ & $32 / 29(20.0)$ & $27 / 26(31.7)$ & $<0.08$ \\
Myalgia & $39 / 39(17.2)$ & $27 / 27(18.6)$ & $12 / 12(14.6)$ & $<0.36$ \\
\hline
\end{tabular}

alone (Hadziyannis and others 2004; Reddy and others 2007). The cumulative doses of RBV observed during the first 3 months have been shown to be predictive of SVR (Bain and others 2008), and very high doses of RBV have led to high SVR rates (Lindahl and others 2005; Bain and others 2008). An optimal early exposure to RBV, as measured by a week 4 trough concentration or better by a day 1 abbreviated area under the concentration curve, has been shown to be predictive of SVR (Loustaud-Ratti and others 2008; Maynard and others 2008). However, the main adverse effect of $\mathrm{RBV}$ is hemolytic anemia, which may require RBV dose reduction and thus compromise SVR. Anemia requiring EPO during the first 8 weeks of treatment has been shown to be predictive of SVR (McHutchison and others 2009). Studies have shown a beneficial role of recombinant EPO in alleviating RBV-induced anemia, thereby improving quality of life and furthermore permitting the maintenance of a high RBV dosage. However, few reports have studied the effect of EPO on SVR (Dieterich and others, 2003; Shiffman and others, 2007; Bertino and others, 2010; Falasca and others, 2010; Alavian and others, 2012).

Our study is the first randomized, prospective controlled study testing the impact of EPO on SVR. We found that patients in the EPO group for whom the initial standard dose of RBV [adapted according to body weight $(<$ or $\geq 75 \mathrm{~kg}$ )
1,000 or $1,200 \mathrm{mg}$ daily] was maintained through the use of EPO after anemia onset had a rate of SVR slightly greater compared with the control patients, although the difference did not reach statistical significance. Some factors may have influenced our results.

(1) We conducted a pragmatic, "real life" study. Experienced physicians involved in this study were aware of the importance of maintaining a RBV dose to obtain a high rate of SVR, and thus, they did not reduce the dose of RBV according to the drug registration recommendations in the control group. RBV dose reduction occurred less often in the EPO group, but this did not result in a significantly higher cumulative dose of RBV for those patients after 8,12 , and 24 weeks of treatment.

(2) The global virological response for all treated patients was rather high (52\%) for a real life study, including a high rate of patients with significant clinical fibrosis (46.3\%), probably because the patients received thorough care. This relatively high rate of response may have masked the beneficial effect of EPO.

(3) The limited improvement provided by the EPO strategy may also be explained by a disequilibrium of genetic polymorphisms that might have affected treatment re-

Table 6. Predictive Factors for Sustained Virological Response in Multivariate Analysis

\begin{tabular}{lllr}
\hline Population & \multicolumn{1}{c}{ Factors } & \multicolumn{1}{c}{ OR $(95 \%$ CI) } & P value \\
\hline Model 1: Global & HCV RNA level (log IU/mL) & $0.579(0.375-0.894)$ & 0.014 \\
& GGT (U/L) & $0.993(0.988-0.998)$ & 0.005 \\
Model 2: Global with host genetic parameter & AST/ALT ratio & $0.261(0.082-0.832)$ & 0.023 \\
& HCV RNA level (log IU/mL) & $0.237(0.097-0.574)$ & 0.001 \\
& ss469415590 & $9.575(2.556-35.868)$ & 0.001 \\
Model 3: ITT & CSF & $0.250(0.094-0.665)$ & 0.005 \\
& HCV RNA level (log IU/mL) & $0.339(0.238-0.668)$ & $<0.001$ \\
Model 4: ITT with host genetic parameter & Iron $(\mu \mathrm{M})$ & $0.947(0.909-0.986)$ & 0.008 \\
& AST/ALT ratio & $0.336(0.123-0.986)$ & 0.033 \\
& HCV RNA level $(\log \mathrm{IU} / \mathrm{mL})$ & $0.183(0.065-0.515)$ & 0.001 \\
& ss469415590 & $5.424(1.362-21.596)$ & 0.016 \\
& Iron $(\mu \mathrm{M})$ & $0.916(0.852-0.983)$ & 0.016 \\
\hline
\end{tabular}

OR, odds-ratio; 95\% CI, 95\% confidence interval; GGT, $\gamma$-glutamyl transferase; CSF, clinically significant fibrosis. 
Table 7. Predictive Factors for Anemia at Week 4 and During Treatment

\begin{tabular}{lllr}
\hline Anemia & \multicolumn{1}{c}{ Parameters } & OR $(95 \%$ CI) & P value \\
\hline Model 1: GP_during treatment without including SNP & Age (years) & $1.095(1.048-1.143)$ & $<0.001$ \\
& Baseline Hb (g/L) & $0.591(0.449-0.778)$ & 0.005 \\
Model 2: GP_during treatment including SNP & Age (years) & $1.147(1.072-1.228)$ & $<0.001$ \\
& Baseline Hb (g/L) & $0.611(0.339-0.936)$ & 0.024 \\
Model 3: GP_at week 4 without including SNP & RBC count (g/L) & $0.130(0.049-0.350)$ & $<0.001$ \\
& Creatinine (mM) & $1.042(1.013-1.072)$ & 0.004 \\
& Haptoglobin (g/L) & $0.359(0.162-0.798)$ & 0.012 \\
Model 4: GP_at week 4 including SNP & RBC count (g/L) & $0.076(0.017-0.346)$ & 0.013 \\
& Creatinine (mM) & $1.052(1.011-1.095)$ & $<0.001$ \\
Model 5: ITT_at week 4 without including SNP & RBC count (g/L) & $0.200(0.074-0.539)$ & $<0.001$ \\
& Creatinine (mM) & $1.034(1.005-1.064)$ & 0.021 \\
& Haptoglobin (g/L) & $0.398(0.168-0.943)$ & 0.036 \\
Model 6: ITT_at week 4 including SNP & Baseline Hb (g/L) & $0.326(0.194-0.677)$ & $<0.001$ \\
& Creatinine (mM) & $1.048(1.004-1.094)$ & 0.032 \\
\hline
\end{tabular}

SNP, single-nucleotide polymorphism; RBC, red blood cell.

sponse (ie, IFNL3 polymorphism) or anemia occurrence/severity (ie, ITPA polymorphism). However, the respective repartitions of these polymorphisms were not statistically different between the overall and ITT control and EPO groups (Tables 1 and 2).

The multivariate analysis of predictive factors of SVR (including genetic factors) was an important element of our study. Interestingly, as already reported, the 2 main factors associated with SVR were the IFNL4 ss469415590 and the pretreatment viral load (Real and others 2014). Like Real and others, we too found that the AUC of the logistic regression model constructed with the IFNL4 ss469415590 was higher than that constructed with IFNL3 rs12979860, but with no significant differences between the AUCs in the 2 populations. We also found that the ITPA polymorphism was associated with neither virologi- cal response nor anemia severity in multivariate analysis (Tables 5 and 6).

Our results are in accordance with previous nonrandomized studies, except for improvement of quality of life, which was not observed in our EPO-treated group. In the study by Shiffman et al., the virological response was higher in patients receiving high doses of RBV+EPO compared to those treated with a lower dose of RBV+/-EPO (Shiffman and others 2007). We obtained a SVR in our global population $(52 \%)$ similar to the one reported by Cash and others (2010). However, SVR was higher in our ITT population (57.4\% with EPO versus $52.4 \%$ without EPO) and in our per protocol population (60.3\% with EPO versus $55.8 \%$ without EPO), illustrating an effect of EPO on SVR, even if this impact was lower than expected $(+5 \%)$. There were high gamma risks in our ITT and per protocol populations (26.6\% and $31.0 \%$, respectively), suggesting a $25 \%$
FIG. 2. Mean changes for SF-36, HQLQ, FSS, and VAS scores between day 0 and week 24 in the ITT population. ITT, intention-to-treat; PF, physical functioning; RP, role physical; BP, bodily pain; $\mathrm{GH}$, general health; $\mathrm{V}$, vitality; SF, social functioning; RE, role emotional; $\mathrm{MH}$, mental health; $\mathrm{Hd}$, health distress; Pwb, positive well-being; Hsl, hepatitisspecific limitations; Hshd, hepatitis-specific health distress; FSS, fatigue severity scale; VAS, visual analog scale; SF-36, Short Form Health Survey 36 Items; HQLQ, Hepatitis Quality of Life Questionnaire.

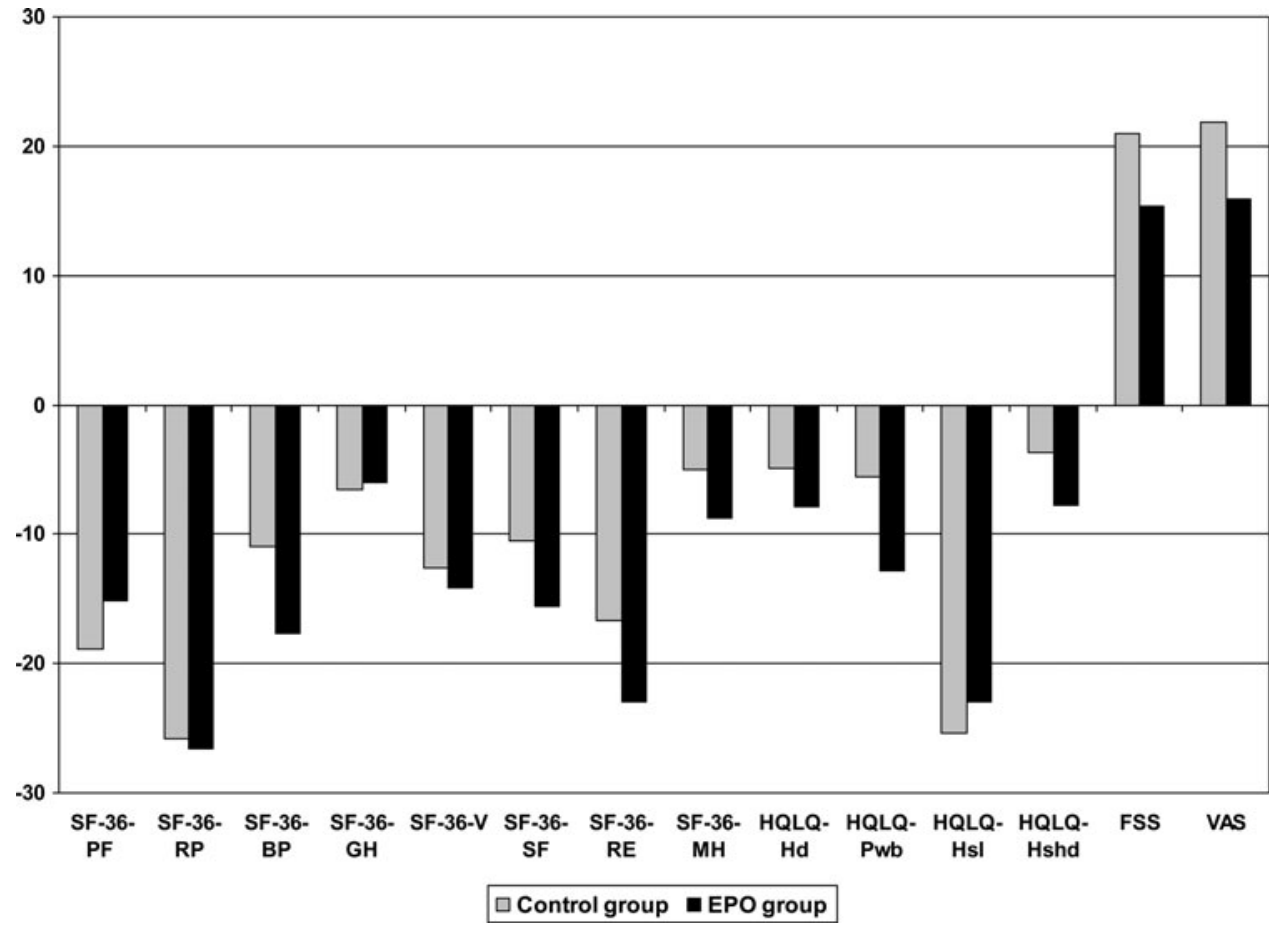


risk of concluding wrong. In a retrospective cohort study on 5,944 patients (of whom 915 received EPO), Backus and others (2007) also found that the use of EPO was a predictive factor of SVR in multivariate analysis.

Earlier studies have suggested that peg-IFN+RBV was responsible for the majority of adverse events during treatment, in contrast to EPO, which was linked with few (Afdhal and others 2004).

Although new highly active $\mathrm{HCV}$ treatments are available, their cost is so high that peg-IFN+RBV remains an option, even in developed countries, especially in patients with favorable predictive factors for SVR, ie, HCV genotype, low viral load, low fibrosis score, and favorable IFNL3 and IFNL4 polymorphisms.

In countries with no or low access to new DAAs, it may be thus well founded to systematically assess pretreatment predictive factors of response if available (baseline viral load, evaluation of liver fibrosis, viral genotype, genetic polymorphism, and so on) before deciding on a therapeutic strategy. Peg-IFN+RBV could then be proposed when patients have a high chance of response [ie, those with favorable IFNL4 or IFNL3 and low viral load $(<800,000 \mathrm{IU} / \mathrm{mL})$, who had a $100 \%$ chance of response to treatment in our study]. Moreover, close management of on-treatment patients to identify those who achieve a rapid virological response (ie, undetectable HCV RNA after 4 weeks of treatment) would extend limited budgets and permit the treatment of more patients with pegIFN+RBV, with an ensuing increase in SVR (Heidrich and others 2014; Pearlman and Ehleben 2014).

Currently, in low-income countries, peg-IFN+RBV remains the SOC for the treatment of chronic hepatitis $C$. RBV may cause anemia, but reducing RBV dose decreases the response rate. In practice, EPO is frequently used to address anemia. However, our study suggests that when systematically prescribed once a definition of "anemia" has been reached, it only has a slightly favorable effect on SVR. Thus, we cannot recommend the systematic use of EPO in cases of RBV-induced anemia; instead, its use might be best reserved for patients who tolerate anemia poorly.

\section{Acknowledgments}

The authors thank the clinical research center of the University Hospital of Angers for its help in conducting this clinical trial (Nathanaëlle Trichereau, Jean-Marie Chrétien, Catherine Hue), the biobank of the University Hospital of Angers (Odile Blanchet, Annick Barthelaix-Pouplard), Marie-Laure Gervais and Adeline Pivert for their technical help in IFNL3 genotyping, and Alain Morel and Michelle Boisdron-Celle for providing them with access to the pyrosequencing equipment.

All PEGEPO study collaborators for the clinical trial are listed in Appendix 1.

The authors thank Kevin L. Erwin for his careful proofreading of the manuscript.

This trial was financed by a research grant from Roche France. IFNL3 determination was partially financed by the French National Agency for AIDS and Viral Hepatitis Research (ANRS) and Roche France.

\section{Author Disclosure Statement}

The authors declare that no competing financial interests exist.

\section{References}

Afdhal NH, Dieterich DT, Pockros PJ, Schiff ER, Shiffman ML, Sulkowski MS, Wright T, Younossi Z, Goon BL, Tang KL, Bowers PJ. 2004. Epoetin alfa maintains ribavirin dose in HCV-infected patients: a prospective, double-blind, randomized controlled study. Gastroenterology 126(5):1302-1311.

Agence Nationale d'Accréditation et d'Evaluation en Santé (ANAES). 2002. Consensus conference. Treatment of hepatitis C. Gastroenterol Clin Biol 26 Spec No 2:B303-B320.

Alavian SM, Tabatabaei SV, Behnava B. 2012. Impact of erythropoietin on sustained virological response to peginterferon and ribavirin therapy for $\mathrm{HCV}$ infection: a systematic review and meta-analysis. J Viral Hepat 19(2):88-93.

Backus LI, Boothroyd DB, Phillips BR, Mole LA. 2007. Predictors of response of US veterans to treatment for the hepatitis C virus. Hepatology 46(1):37-47.

Bain VG, Lee SS, Peltekian K, Yoshida EM, Deschenes M, Sherman M, Bailey R, Witt-Sullivan H, Balshaw R, Krajden M. 2008. Clinical trial: exposure to ribavirin predicts EVR and SVR in patients with HCV genotype 1 infection treated with peginterferon alpha-2a plus ribavirin. Aliment Pharmacol Ther 28(1):43-50.

Balan V, Schwartz D, Wu GY, Muir AJ, Ghalib R, Jackson J, Keeffe EB, Rossaro L, Burnett A, Goon BL, Bowers PJ, Leitz GJ. 2005. Erythropoietic response to anemia in chronic hepatitis $\mathrm{C}$ patients receiving combination pegylated interferon/ribavirin. Am J Gastroenterol 100(2):299-307.

Bayliss MS, Gandek B, Bungay KM, Sugano D, Hsu MA, Ware JE, Jr. 1998. A questionnaire to assess the generic and diseasespecific health outcomes of patients with chronic hepatitis C. Qual Life Res 7(1):39-55.

Bertino G, Ardiri A, Boemi PM, Calvagno GS, Ruggeri IM, Speranza A, Santonocito MM, Ierna D, Bruno CM, Valenti M, Boemi R, Naimo S, Neri S. 2010. Epoetin alpha improves the response to antiviral treatment in HCV-related chronic hepatitis. Eur J Clin Pharmacol 66(10):1055-1063.

Cash WJ, Patterson K, Callender ME, McDougall NI. 2010. Adjuvant therapy used in conjunction with combination therapy for chronic hepatitis $\mathrm{C}$ improves sustained virus response rates in genotype 1 patients. J Viral Hepat 17(4): 269-273.

Chapko MK, Dominitz JA. 2006. Cost-effectiveness of growth factors during hepatitis $\mathrm{C}$ anti-viral therapy. Aliment Pharmacol Ther 24(7):1067-1077.

Dalgard O, Egeland A, Skaug K, Vilimas K, Steen T. 2004. Health-related quality of life in active injecting drug users with and without chronic hepatitis $\mathrm{C}$ virus infection. Hepatology 39(1):74-80.

Di Bisceglie AM, Martin P, Kassianides C, Lisker-Melman M, Goodman Z, Banks SM, Hoofnagle JH. 1990. A randomized, double-blind, placebo-controlled trial of recombinant human alpha-interferon therapy for chronic non-A, non-B (type C) hepatitis. J Hepatol 11 Suppl 1:S36-S42.

Dieterich DT, Spivak JL. 2003. Hematologic disorders associated with hepatitis $\mathrm{C}$ virus infection and their management. Clin Infect Dis 37(4):533-541.

Dieterich DT, Wasserman R, Brau N, Hassanein TI, Bini EJ, Bowers PJ, Sulkowski MS. 2003. Once-weekly epoetin alfa improves anemia and facilitates maintenance of ribavirin dosing in hepatitis $\mathrm{C}$ virus-infected patients receiving ribavirin plus interferon alfa. Am J Gastroenterol 98(11):2491-2499.

Falasca K, Ucciferri C, Mancino P, Gorgoretti V, Pizzigallo E, Vecchiet J. 2010. Use of epoetin beta during combination therapy of infection with hepatitis c virus with ribavirin improves a sustained viral response. J Med Virol 82(1):49-56. 
Fried MW, Shiffman ML, Reddy KR, Smith C, Marinos G, Goncales FL, Jr., Haussinger D, Diago M, Carosi G, Dhumeaux D, Craxi A, Lin A, Hoffman J, Yu J. 2002. Peginterferon alfa-2a plus ribavirin for chronic hepatitis $\mathrm{C}$ virus infection. $\mathrm{N}$ Engl $\mathrm{J}$ Med 347(13):975-982.

Ge D, Fellay J, Thompson AJ, Simon JS, Shianna KV, Urban TJ, Heinzen EL, Qiu P, Bertelsen AH, Muir AJ, Sulkowski M, McHutchison JG, Goldstein DB. 2009. Genetic variation in IL28B predicts hepatitis C treatment-induced viral clearance. Nature 461(7262):399-401.

Hadziyannis SJ, Papatheodoridis GV. 2003. Peginterferonalpha2a (40 kDa) for chronic hepatitis C. Expert Opin Pharmacother 4(4):541-551.

Hadziyannis SJ, Sette H, Jr., Morgan TR, Balan V, Diago M, Marcellin P, Ramadori G, Bodenheimer H, Jr., Bernstein D, Rizzetto M, Zeuzem S, Pockros PJ, Lin A, Ackrill AM. 2004. Peginterferon-alpha2a and ribavirin combination therapy in chronic hepatitis $\mathrm{C}$ : a randomized study of treatment duration and ribavirin dose. Ann Intern Med 140(5):346-355.

Heidrich B, Wiegand SB, Buggisch P, Hinrichsen H, Link R, Moller B, Boker KH, Teuber G, Klinker H, Zehnter E, Naumann U, Busch HW, Maasoumy B, Baum U, Hardtke S, Manns MP, Wedemeyer H, Petersen J, Cornberg M. 2014. Treatment of naive patients with chronic hepatitis $\mathrm{C}$ genotypes 2 and 3 with pegylated interferon alpha and ribavirin in a real world setting: relevance for the new era of DAA. PLoS One 9(10): e108751.

Hoofnagle JH, Mullen KD, Jones DB, Rustgi V, Di Bisceglie A, Peters M, Waggoner JG, Park Y, Jones EA. 1986. Treatment of chronic non-A,non-B hepatitis with recombinant human alpha interferon. A preliminary report. N Engl J Med 315(25):15751578.

Jimenez-Sousa MA, Fernandez-Rodriguez A, GuzmanFulgencio M, Garcia-Alvarez M, Resino S. 2013. Metaanalysis: implications of interleukin-28B polymorphisms in spontaneous and treatment-related clearance for patients with hepatitis C. BMC Med 11:6.

Kwo PY, Lawitz EJ, McCone J, Schiff ER, Vierling JM, Pound D, Davis MN, Galati JS, Gordon SC, Ravendhran N, Rossaro L, Anderson FH, Jacobson IM, Rubin R, Koury K, Pedicone LD, Brass CA, Chaudhri E, Albrecht JK. 2010. Efficacy of boceprevir, an NS3 protease inhibitor, in combination with peginterferon alfa- $2 b$ and ribavirin in treatment-naive patients with genotype 1 hepatitis $\mathrm{C}$ infection (SPRINT-1): an open-label, randomised, multicentre phase 2 trial. Lancet 376(9742):705-716.

Lavanchy D. 2009. The global burden of hepatitis C. Liver Int 29 Suppl 1:74-81.

Lebray P, Nalpas B, Vallet-Pichard A, Broissand C, Sobesky R, Serpaggi J, Fontaine H, Pol S. 2005. The impact of haematopoietic growth factors on the management and efficacy of antiviral treatment in patients with hepatitis $\mathrm{C}$ virus. Antivir Ther 10(6):769-776.

Lindahl K, Stahle L, Bruchfeld A, Schvarcz R. 2005. High-dose ribavirin in combination with standard dose peginterferon for treatment of patients with chronic hepatitis C. Hepatology 41(2):275-279.

Loustaud-Ratti V, Alain S, Rousseau A, Hubert IF, Sauvage FL, Marquet P, Denis F, Lunel F, Cales P, Lefebvre A, Fauchais AL, Liozon E, Vidal E. 2008. Ribavirin exposure after the first dose is predictive of sustained virological response in chronic hepatitis C. Hepatology 47(5):1453-1461.

Manns MP, McHutchison JG, Gordon SC, Rustgi VK, Shiffman M, Reindollar R, Goodman ZD, Koury K, Ling M, Albrecht JK. 2001. Peginterferon alfa-2b plus ribavirin compared with in- terferon alfa- $2 \mathrm{~b}$ plus ribavirin for initial treatment of chronic hepatitis C: a randomised trial. Lancet 358(9286):958-965.

Maynard M, Pradat P, Gagnieu MC, Souvignet C, Trepo C. 2008. Prediction of sustained virological response by ribavirin plasma concentration at week 4 of therapy in hepatitis $\mathrm{C}$ virus genotype 1 patients. Antivir Ther 13(4):607-611.

McHutchison JG, Everson GT, Gordon SC, Jacobson IM, Sulkowski M, Kauffman R, McNair L, Alam J, Muir AJ. 2009. Telaprevir with peginterferon and ribavirin for chronic HCV genotype 1 infection. N Engl J Med 360(18):18271838.

McHutchison JG, Lawitz EJ, Shiffman ML, Muir AJ, Galler GW, McCone J, Nyberg LM, Lee WM, Ghalib RH, Schiff ER, Galati JS, Bacon BR, Davis MN, Mukhopadhyay P, Koury K, Noviello S, Pedicone LD, Brass CA, Albrecht JK, Sulkowski MS. 2009. Peginterferon alfa-2b or alfa-2a with ribavirin for treatment of hepatitis $\mathrm{C}$ infection. $\mathrm{N}$ Engl $\mathrm{J}$ Med 361(6):580-593.

McHutchison JG, Manns M, Patel K, Poynard T, Lindsay KL, Trepo C, Dienstag J, Lee WM, Mak C, Garaud JJ, Albrecht JK. 2002. Adherence to combination therapy enhances sustained response in genotype-1-infected patients with chronic hepatitis C. Gastroenterology 123(4):1061-1069.

Meffre C, Le Strat Y, Delarocque-Astagneau E, Dubois F, Antona D, Lemasson JM, Warszawski J, Steinmetz J, Coste D, Meyer JF, Leiser S, Giordanella JP, Gueguen R, Desenclos JC. 2010. Prevalence of hepatitis B and hepatitis C virus infections in France in 2004: social factors are important predictors after adjusting for known risk factors. J Med Virol 82(4):546-555.

Pearlman BL, Ehleben C. 2014. Hepatitis C genotype 1 virus with low viral load and rapid virologic response to peginterferon/ ribavirin obviates a protease inhibitor. Hepatology 59(1):71-77.

Pockros PJ, Shiffman ML, Schiff ER, Sulkowski MS, Younossi Z, Dieterich DT, Wright TL, Mody SH, Tang KL, Goon BL, Bowers PJ, Leitz G, Afdhal NH. 2004. Epoetin alfa improves quality of life in anemic $\mathrm{HCV}$-infected patients receiving combination therapy. Hepatology 40(6):1450-1458.

Real LM, Neukam K, Herrero R, Guardiola JM, Reiberger T, Rivero-Juarez A, Salazar J, Mandorfer M, Merino D, Soriano V, Rivero A, Macias J, Pineda JA, Caruz A. 2014. IFNL4 ss469415590 variant shows similar performance to rs12979860 as predictor of response to treatment against hepatitis $\mathrm{C}$ virus genotype 1 or 4 in Caucasians. PLoS One 9(4):e95515.

Reddy KR, Shiffman ML, Morgan TR, Zeuzem S, Hadziyannis S, Hamzeh FM, Wright TL, Fried M. 2007. Impact of ribavirin dose reductions in hepatitis $\mathrm{C}$ virus genotype 1 patients completing peginterferon alfa-2a/ribavirin treatment. Clin Gastroenterol Hepatol 5(1):124-129.

Reddy KR, Wright TL, Pockros PJ, Shiffman M, Everson G, Reindollar R, Fried MW, Purdum PP, 3rd, Jensen D, Smith C, Lee WM, Boyer TD, Lin A, Pedder S, DePamphilis J. 2001. Efficacy and safety of pegylated (40-kd) interferon alpha-2a compared with interferon alpha-2a in noncirrhotic patients with chronic hepatitis C. Hepatology 33(2):433-438.

Ronaghi M. 2001. Pyrosequencing sheds light on DNA sequencing. Genome Res 11(1):3-11.

Royo JL, Galan JJ. 2009. Pyrosequencing for SNP genotyping. Methods Mol Biol 578:123-133.

Schwartz D, Lellouch J. 2009. Explanatory and pragmatic attitudes in therapeutical trials. J Clin Epidemiol 62(5):499-505.

Shiffman ML, Salvatore J, Hubbard S, Price A, Sterling RK, Stravitz RT, Luketic VA, Sanyal AJ. 2007. Treatment of chronic hepatitis $\mathrm{C}$ virus genotype 1 with peginterferon, ribavirin, and epoetin alpha. Hepatology 46(2):371-379. 
Sterling RK, Lissen E, Clumeck N, Sola R, Correa MC, Montaner J, Sulkowski M, Torriani FJ, Dieterich DT, Thomas DL, Messinger D, Nelson M. 2006. Development of a simple noninvasive index to predict significant fibrosis in patients with HIV/HCV coinfection. Hepatology 43(6):1317-1325.

Suppiah V, Moldovan M, Ahlenstiel G, Berg T, Weltman M, Abate ML, Bassendine M, Spengler U, Dore GJ, Powell E, Riordan S, Sheridan D, Smedile A, Fragomeli V, Muller T, Bahlo M, Stewart GJ, Booth DR, George J. 2009. IL28B is associated with response to chronic hepatitis $\mathrm{C}$ interferonalpha and ribavirin therapy. Nat Genet 41(10):1100-1104.

Talal AH, Weisz K, Hau T, Kreiswirth S, Dieterich DT. 2001. A preliminary study of erythropoietin for anemia associated with ribavirin and interferon-alpha. Am J Gastroenterol 96(9):28022804.

Tanaka Y, Nishida N, Sugiyama M, Kurosaki M, Matsuura K, Sakamoto N, Nakagawa M, Korenaga M, Hino K, Hige S, Ito Y, Mita E, Tanaka E, Mochida S, Murawaki Y, Honda M, Sakai A, Hiasa Y, Nishiguchi S, Koike A, Sakaida I, Imamura M, Ito K, Yano K, Masaki N, Sugauchi F, Izumi N, Tokunaga K, Mizokami M. 2009. Genome-wide association of IL28B with response to pegylated interferon-alpha and ribavirin therapy for chronic hepatitis C. Nat Genet 41(10):1105-1109.
Vergara IA, Norambuena T, Ferrada E, Slater AW, Melo F. 2008. StAR: a simple tool for the statistical comparison of ROC curves. BMC Bioinformatics 9:265.

Wai CT, Greenson JK, Fontana RJ, Kalbfleisch JD, Marrero JA, Conjeevaram HS, Lok AS. 2003. A simple noninvasive index can predict both significant fibrosis and cirrhosis in patients with chronic hepatitis C. Hepatology 38(2):518-526.

Witt S, Neumann J, Zierdt H, Gebel G, Roscheisen C. 2012. Establishing a novel automated magnetic bead-based method for the extraction of DNA from a variety of forensic samples. Forensic Sci Int Genet 6(5):539-547.

\author{
Address correspondence to: \\ Dr. Françoise Lunel-Fabiani \\ Department of Virology \\ University Hospital of Angers \\ Angers 49933 \\ France
}

E-mail: frlunel-fabiani@chu-angers.fr

\section{Appendix 1}

\section{The PEGEPO Study Group Included the Following Members}

A. Abergel, Department of Hepatology and Gastroenterology, University Hospital Estaing, Université d'Auvergne, UMR 6284, Clermont-Ferrand, France.

J.P. Arpurt, Department of Hepatology and Gastroenterology, Hospital of Avignon, Avignon, France.

Y. Bacq, Department of Hepatology and Gastroenterology, University Hospital of Tours, 37170 Chambrayles-Tours, France.

D. Barbereau, Department of Hepatology and Gastroenterology, University Hospital of Tours, 37170 Chambrayles-Tours, France.

C. Bonny, Department of Hepatology and Gastroenterology, University Hospital Estaing, Université d'Auvergne, UMR 6284, Clermont-Ferrand, France.

C. Castelnau, Department of Hepatology, Physiopathology and Treatment of Viral Hepatitis, Hospital of Beaujon, AP-HP, 92110 Clichy, France.

J.P. Cervoni, Department of Hepatology, University Hospital Jean Minjoz, Université de Franche-Comté, Besançon, France.

D. Cohen, Department of Hepatology, Gastroenterology and Nutrition, University Hospital of Caen, 14033 Caen, France.

H. Danièlou, Department of Liver Diseases, University Hospital of Rennes, Rennes, France.

M. Debette-Gratien, Department of Hepatology and Gastroenterology, University Hospital of Limoges, 87042 Limoges, France.

P. Delasalle, Department of Hepatology and Gastroenterology, Clinique du Palais, Grasse, France.
J. Denis, Department of Hepatology and Gastroenterology, Sud-francilien Hospital, 91106 Corbeil-Essonnes, France.

V. Di Martino, Department of Hepatology, University Hospital Jean Minjoz, Université de Franche-Comté, Besançon, France.

T. Fontanges, Department of Hepatology and Gastroenterology, Hospital of Pierre Oudot, Bourgoin-Jallieu, France.

O. Goria, Department of Hepatology and Gastroenterology, University Hospital Charles Nicolle, Rouen, France.

J. Gournay, Department of Hepatology and Gastroenterology, Hôtel-Dieu hospital, University Hospital of Nantes, Nantes, France.

J.D. Grangé, Department of hepatology, Hospital of Tenon, AP-HP, Paris, France.

C. Guillemard, Department of Hepatology, Gastroenterology and Nutrition, University Hospital of Caen, 14033 Caen, France.

P. Hillon, Department of Hepatology and Gastroenterology, University Hospital of Dijon, Université de Bourgogne, Dijon, France.

S. Hommel, Department of Hepatology and Gastroenterology, University Hospital Charles Nicolle, Rouen, France.

V. Leroy, Department of Hepatology and Gastroenterology, University Hospital of Grenoble, INSERM U823, 38043 Grenoble, France.

M. Maynard, Department of Hepatology and Gastroenterology, Hospices Civils of Lyon, Lyon, France.

P. Mélin, Department of Polyvalent Medicine and Specialities, Hospital of Geneviève de Gaulle Anthonioz, SaintDizier, France. 
P. Mercet, Department of Hepatology, University Hospital Jean Minjoz, Université de Franche-Comté, Besançon, France.

A. Minello, Department of Hepatology and Gastroenterology, University Hospital of Dijon, Université de Bourgogne, Dijon, France.

B. Nalet, Department of Hepatology and Gastroenterology, Hospital of Montélimar, Montélimar, France.

F. Oberti, Department of Hepatology and Gastroenterology, University Hospital of Angers, 49933 Angers, France.

A. Pariente, Department of Hepatology and Gastroenterology, Hospital of Pau, Pau, France.

J.L. Payen, Department of Hepatology and Gastroenterology, Hospital of Montauban, Montauban, France.

M. Picon-Coste, Department of Hepatology and Gastroenterology, Hospital of Pays d'Aix en Provence, Aix en Provence, France.

C. Pilette, Department of Hepatology and Gastroenterology, Hospital of Le Mans, Le Mans, France.

C. Richou, Department of Hepatology, University Hospital Jean Minjoz, Université de Franche-Comté, Besançon, France.

M.P. Ripault, Department of Hepatology, Physiopathology and Treatment of Viral Hepatitis, Hospital of Beaujon, AP-HP, 92110 Clichy, France.
M. Schnee, Department of Hepatology and Gastroenterology, Hospital of Vendée, La Roche-sur-Yon, France.

S.N. Si Ahmed, Department of Hepatology and Gastroenterology and Digestive Oncology, Hospital of La Source, Orléans, France.

C. Silvain, Department of Hepatology and Gastroenterology, University Hospital of Poitiers, Poitiers, France.

N. Talbodec, Department of Hepatology and Gastroenterology, Hospital of G. DRON, Tourcoing, France.

F. Tanné, Department of Hepatology and Gastroenterology, University Hospital of la Cavale Blanche, Brest, France.

T. Thévenot, Department of Hepatology, University Hospital Jean Minjoz, Université de Franche-Comté, Besançon, France.

B. Tissot, Department of Hepatology and Gastroenterology, Hospital of Le Mans, Le Mans, France.

J.P. Toudic, Department of Hepatology, Gastroenterology and Nutrition, University Hospital of Caen, 14033 Caen, France.

C. Vanlemmens, Department of Hepatology, University Hospital Jean Minjoz, Université de Franche-Comté, Besançon, France.

J.P. Zarski, Department of Hepatology and Gastroenterology, University Hospital of Grenoble, INSERM U823, 38043 Grenoble, France. 